\title{
The role of cell based therapy in the treatment of Parkinson's disease
}

\author{
Ahmad Farid Habibyar ${ }^{1 *}$ \\ ${ }^{1}$ Lecturer at Kabul University, Pharmacy Faculty, Pharmacology Department, Kabul, Afghanistan
}

\begin{abstract}
Parkinson's disease (PD) is considered to be the second common neurodegenerative illness after Alzheimer's disease worldwide. It affects 1-2\% of the world population. $\mathrm{PD}$ is associated with motor symptoms such as bardykinesia, resting tremor, muscle rigidity. Additionally, non-motor symptoms of PD include sleep disturbance, depression and postural instability. These all PD symptoms are attributed to the selective and progressive degeneration of dopaminergic neurons in the substantia nigra pars compacta. A number of pharmacological agents are today available for the treatment of PD. These medications are associated with adverse drug events or lack of efficacy in some patients. Therefore it is required to explore novel methods for the treatment of PD i.e., cell based therapy. A number of cell based therapeutics is tried for the treatment of PD such as embryonic stem cells, induced pluripotent stem cells and somatic stem cells. Although this novel method proved to be effective in PD treatment in animal and clinical studies. But on the other hand it leads to the worsening of the non-motor symptoms. Thus, these studies are not enough, more long term clinical trials are required to proof the efficacy of all aspects of PD through cell based therapy including non-motor symptoms.
\end{abstract}

\section{Introduction}

Until the second half of the $20^{\text {th }}$ century, it was believed that the human nervous system can never be repaired, even in the future. Ultimately, later through research, it was reported that by grafting dopamine containing mesencephalic tissue into the rat brain, signs of Parkinson's disease (PD) can be improved [1,2].

$\mathrm{PD}$ is considered to be the second common neurodegenerative disorder after Alzheimer's disease (AD) globally. PD affects about $1-2 \%$ of the world $[3,4]$. Clinically PD is presented with bardykinesia, resting tremor, muscle rigidity and postural instability. These all PD manifestations are attributed to the selective and progressive degeneration of dopaminergic neurons in the substantia nigra pars compacta [5]. The genetic and environmental factors are believed to be involved in the etiology of PD [6,7]. Factors involved in the pathogenesis of PD include neuroinflammation, mitochondrial dysfunction, protein degradation failure, endoplasmic reticulum stress, and over production of the reactive oxygen species [8-14]. Regrettably, there are still challenges with the clear understanding of PD and its mechanisms. Moreover, available treatments are curing only the symptoms i.e. they cannot modify or prevent the progression of disease. PD is clinically diagnosed with motor symptoms as mentioned earlier. But non-motor symptoms can also be seen in most of the patients. These non-motor symptoms include depression, sleeplessness, fatigue, dementia, and pain. The therapy of PD is focusing mainly on the replacement or supplement of dopamine (DA). Today, a number of dopaminergic drugs and new therapeutic candidates have been developed and subjected to clinical trials [15]. Despite these all efforts made for the therapy of PD, still there are some challenges with currently available treatments. For example, levodopa, although it is an effective medication in most PD patients, it can lead to dyskinesia a motor complication, also it causes motor fluctuation. The emergence of dyskinesias and other motor complications, indicate that the patient has gone into an advanced stage of PD. Thus it is required to change the levodopa dosage, as well as combine it with other anti-PD medications. The motor symptoms of PD (tremors, dyskinesias) can be treated with currently available medications, but on the contrary features such as postural imbalance and neuropsychiatric problems of PD are not appropriately responding to currently available medications, thus they need other approaches $[16,17]$. All of the above problems, state that there is a big need to search alternative way i.e. cell based therapies for the PD patients. Here, we briefly discuss the effectiveness and challenges of cell based therapies for PD patients (Figure 1).

\section{Cell based therapies for PD}

Now PD patients can take the advantage of cell based therapy. A number of animal and clinical studies proved the efficacy of different stem cell based transplantation therapy. This technique reduced the dosage requirement of anti-PD drugs. Additionally, they improve the motor signs of PD [18-21]. Some of the early studies found that the formation of tumor after embryonic stem cell transplantation is a major drawback of this technique [22,23]. Therefore, it is required to reduce the possibility of tumor formation. For this purpose, a number of strategies have been developed which include persistent pre-differentiation of embryonic stem cells, choosing differentiated stem cells, and taking the advantage of genetic engineering to block the pathways responsible for tumor production [24]. In a research the undifferentiated embryonic stem cells were treated with mitomycin. Then, they were injected into the striatum of the mice, after one year and three months follow up studies. It was found that, the motor symptoms

Correspondence to: Ahmad Farid Habibyar, Lecturer at Kabul University, Pharmacy Faculty, Pharmacology Department, Afghanistan, E-mail: drfaridhabibyar@gmail.com

Received: January 27, 2017; Accepted: February 28, 2017; Published: March 03,2017 


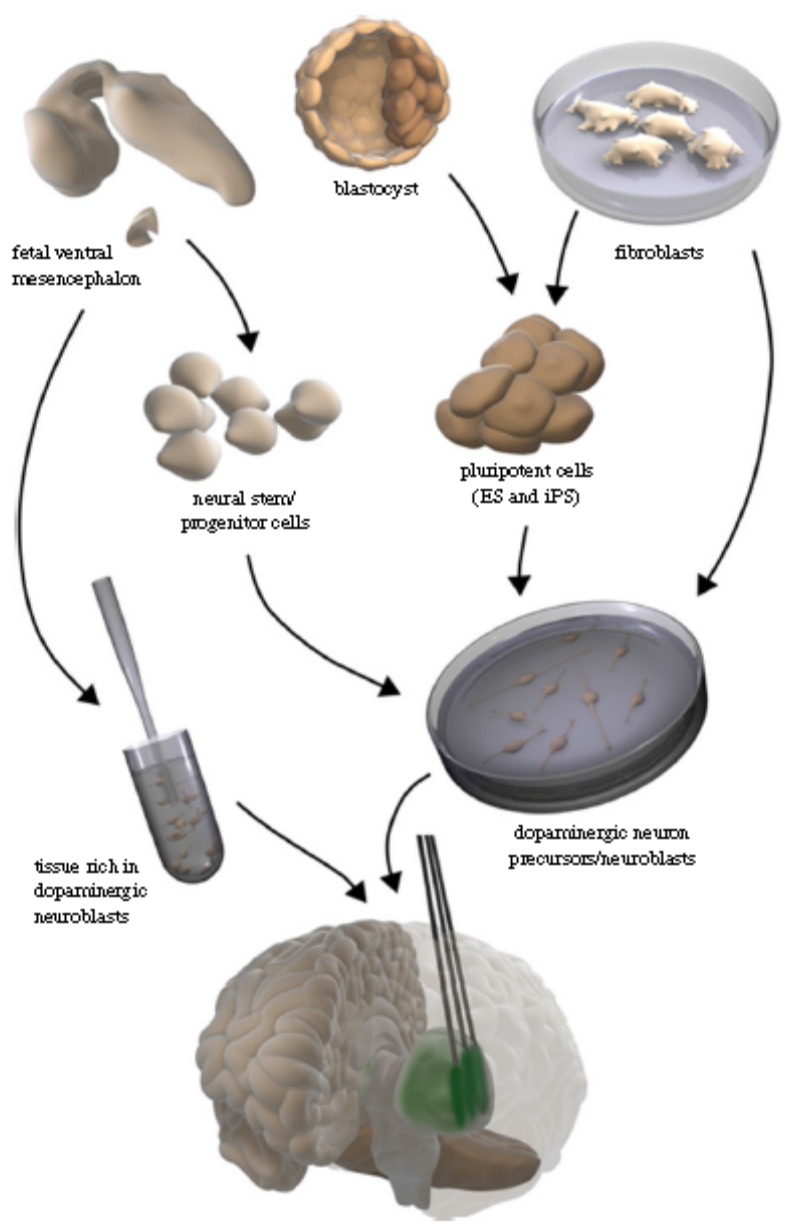

Figure 1. Sources of cell for implantation in PD patients [54].

of the mice were improved remarkably without any tumor production [25]. In addition, preclinical studies also found the safety and efficacy of the human unfertilized cell or induced pluripotent stem cells. These later cells have been found to improve the motor symptoms of PD in the animals $[21,26]$. Similarly, in a 14 year study it was observed that most of the transplanted dopaminergic neurons remained functional and [27]. This was known by the persistent expression of dopamine transporters, mitochondrial shapes. In the following, different cell types with their potential for implanting into the brain of PD patients have been explained:

\section{Mesencephalic tissue of the human fetus}

A number of studies showed that dopamine containing tissue from the human fetus can survive and grow after implantation in the human brain striatum. As this was found through the positron emission tomography and histological studies [28-37]. It has been found that transplantation of the abovementioned tissue can improve movement related problems in PD patients [38]. In a relevant study, it was found that the motor symptoms can improve even for eighteen years after transplantation $[39,40]$. In addition, some studies exist which showed contradictory results which oppose the above findings [41,42]. Additionally, it is found that immune system invasion after six months of discontinuing immunosuppressant drugs can also destroy the graft of human mesencephalic tissue. This can lead to failure of the efficacy of transplanting mesencephalic tissue [43].

\section{Human embryonic stem cells}

This type of transplantation was found to be effective in a rat model of PD [44]. After grafting this type of cells, they were able to generate large numbers of dopaminergic neurons in the substantia nigra. But the drawback was production of tumor. On the other hand some other researchers used new protocols to convert embryonic stem cells into the dopaminergic neurons and inhibit tumor generation as well. These protocols have various merits like production of a large number of dopaminergic neurons in the area required i.e. substantia nigra, survival and re-innervation of the degenerated parts in the striatum [45]. Additionally, in a rat model of PD, it was also found that human embryonic stem cells are comparably potent to that of the mesencephalic tissue of the human fetus (in terms of growth, survival, as well as efficacy), but the major drawback is the safety concern [46].

\section{Human somatic cells}

The human dopaminergic neurons can be produced using a technology called pluripotent. In this technology, the human fibroblasts can be reprogrammed through a pluripotent stage [47-51]. Additionally, dopaminergic neurons specific to the patients can be generated, thus it avoids the activity of immune system as well as the ethical issue of the embryonic stem cells. The major drawbacks associated with this technology is the tumor production, unpredictability in the process of reprogramming, and making prone to the pathogenesis of PD [52].

\section{Points to be considered before choosing cell based therapy for PD patients}

Although different types of stem cells including induced pluripotent stem cells, embryonic stem cells are tried for the therapy of PD at preclinical level. But few of them proved to be clinically effective. Before clinical use of stem cell-derived therapies for PD patients, it is required to consider the tumorigenic potential, sources of cell, optimal transplantation protocols, reliable delivery system, transplantation locations and timing [53]. Additionally, it is required to know the challenges associated with cell transplantation. These challenges include potency, safety and proper patient selection for cell transplantation [54].

\section{Conclusion}

There has been a stable development in the field of cell based therapy for PD since the introduction of this technique 30 years ago. Embryonic stem cells, induced pluripotent stem cells and somatic stem cells are among the cell based techniques used for the PD treatment. For developing cell based therapies as a more effective treatment to the PD patients, it is required to test these cell based therapies in the proper patient population, according to the standard protocols, using proper cell preparation, implantation techniques.

\section{References}

1. Björklund A, Stenevi U (1979) Reconstruction of the nigrostriatal dopamine pathway by intracerebral nigral transplants. Brain Res 177: 555-560. [Crossref]

2. Perlow MJ, Freed WJ, Hoffer BJ, Seiger A, Olson L, et al. (1979) Brain grafts reduce motor abnormalities produced by destruction of nigrostriatal dopamine system. Science 204: 643-647. [Crossref]

3. Healy DG, Falchi M, O'Sullivan SS, Bonifati V, Durr A, et al. (2008) International LRRK2 Consortium Phenotype, genotype, and worldwide genetic penetrance of LRRK2-associated Parkinson's disease: a case-control study. Lancet Neurol 7: 583590. [Crossref]

4. Tarsy D (2012) Treatment of Parkinson disease: a 64-year-old man with motor complications of advanced Parkinson disease. JAMA 307: 2305-2314. [Crossref] 
5. Fahn S (2003) Description of Parkinson's disease as a clinical syndrome. Ann N Y Acad Sci 991: 1-14. [Crossref]

6. Warner TT, Schapira AH (2003) Genetic and environmental factors in the cause of Parkinson's disease. Ann Neurol 53 Suppl 3: S16-23. [Crossref]

7. Hirsch EC, Jenner P, Przedborski S (2013) Pathogenesis of Parkinson's disease. Mov Disord 28: 24-30. [Crossref]

8. Kansara S, Trivedi A, Chen S, Jankovic J, Le W (2013) Early diagnosis and therapy of Parkinson's disease: can disease progression be curbed? J Neural Transm (Vienna) 120: 197-210. [Crossref]

9. Shen YF, Tang Y, Zhang XJ, Huang KX, Le WD (2013) Adaptive changes in autophagy after UPS impairment in Parkinson's disease. Acta Pharmacol Sin 34: 667673. [Crossref]

10. Zuo L, Motherwell MS (2013) The impact of reactive oxygen species and genetic mitochondrial mutations in Parkinson's disease. Gene 532: 18-23. [Crossref]

11. Tang Y, Li T, Li J, Yang J, Liu H, et al. (2014) Jmjd3 is essential for the epigenetic modulation of microglia phenotypes in the immune pathogenesis of Parkinson's disease. Cell Death Differ 21: 369-380. [Crossref]

12. Ciechanover A, Kwon YT (2015) Degradation of misfolded proteins in neurodegenerative diseases: therapeutic targets and strategies. Exp Mol Med 47: e147. [Crossref]

13. Michel PP, Hirsch EC, Hunot S (2016) Understanding Dopaminergic Cell Death Pathways in Parkinson Disease. Neuron 90: 675-691. [Crossref]

14. Dong J, Cui Y, Li S, Le W1 (2016) Current Pharmaceutical Treatments and Alternative Therapies of Parkinson's Disease. Curr Neuropharmacol 14: 339-355. [Crossref]

15. Nirenberg MJ, Fahn S (2005) The role of levodopa and catechol-Omethyltransferase inhibitors. In: Schapira AHV, Olanow CW (eds) Principles of treatment in Parkinson's disease. Butterworth- Heinemann Elsevier, Philadelphia 3-24.

16. Schapira AHV, Olanow CW (2005) The medical management of Parkinson's disease. In: Schapira AHV, Olanow CW (eds) Principles of treatment in Parkinson's disease. Butterworth-Heinemann Elsevier, Philadelphia 119-143.

17. O'Keeffe FE, Scott SA, Tyers P, O'Keeffe GW, Dalley JW, et al. (2008) Induction of A9 dopaminergic neurons from neural stem cells improves motor function in an animal model of Parkinson's disease. Brain 131: 630-641. [Crossref]

18. Venkataramana NK, Kumar SK, Balaraju S, Radhakrishnan RC, Bansal A, et al. (2010) Open-labeled study of unilateral autologous bonemarrow- derived mesenchymal stem cell transplantation in Parkinson's disease. Transl Res 155: 62-70. [Crossref]

19. Gonzalez R, Garitaonandia I, Crain A, Poustovoitov M, AbramihinaT, et al. (2015b) Proof of concept studies exploring the safety and functional activity of human parthenogenetic-derived neural stem cells for the treatment of Parkinson's disease. Cell Transplant 24: 681-690. [Crossref]

20. Han F, Wang W, Chen B, Chen C, Li S, et al. (2015) Human induced pluripotent stem cell-derived neurons improve motor asymmetry in a 6-hydroxydopamine-induced rat model of Parkinson's disease. Cytotherapy 17: 665-679. [Crossref]

21. Bjorklund LM, Sa'nchez-Pernaute R, Chung S, Andersson T, Chen IY, et al. (2002) Embryonic stem cells develop into functional dopaminergic neurons after transplantation in a Parkinson rat model. Proc Natl Acad Sci USA 99: 2344-2349. [Crossref]

22. Kim JH, Auerbach JM, Rodríguez-Gómez JA, Velasco I, Gavin D, et al. (2002) Dopamine neurons derived from embryonic stem cells function in an animal model of Parkinson's disease. Nature 418: 50-56. [Crossref]

23. Ambasudhan R, Dolatabadi N, Nutter A, Masliah E, Mckercher SR, et al. (2014) Potential for cell therapy in Parkinson's disease using genetically programmed human embryonic stem cell-derived neural progenitor cells. J Comp Neurol 522: 2845-2856. [Crossref]

24. Acquarone M, de Melo TM, Meireles F, Brito-Moreira J, Oliveira G, et al. (2015) Mitomycin-treated undifferentiated embryonic stem cells as a safe and effective therapeutic strategy in a mouse model of Parkinson's disease. Front Cell Neurosci 9: 97. [Crossref]

25. González C, Bonilla S, Flores AI, Cano E, Liste I1 (2016) An Update on Human Stem Cell-Based Therapy in Parkinson's Disease. Curr Stem Cell Res Ther 11: 561-568. [Crossref]

26. Han F, Wang W, Chen B, Chen C, Li S, et al. (2015) Human induced pluripotent stem cell-derived neurons improve motor asymmetry in a 6-hydroxydopamine-induced rat model of Parkinson's disease. Cytotherapy 17: 665-679. [Crossref]
27. Hallett PJ, Cooper O, Sadi D, Robertson H, Mendez I, et al. (2014) Long-term health of dopaminergic neuron transplants in Parkinson's disease patients. Cell Rep 7: 17551761. [Crossref]

28. Lindvall O (2013) Developing dopaminergic cell therapy for Parkinson's disease--give up or move forward? Mov Disord 28: 268-273. [Crossref]

29. Kordower JH, Chu Y, Hauser RA, Freeman TB, Olanow CW (2008) Lewy bodylike pathology in long-term embryonic nigral transplants in Parkinson's disease. Nat Med 14: 504-506. [Crossref]

30. Kordower JH, Chu Y, Hauser RA, Olanow CW, Freeman TB (2008) Transplanted dopaminergic neurons develop PD pathologic changes: a second case report. Mov Disord 23: 2303-2306. [Crossref]

31. Kordower JH, Freeman TB, Chen EY, Mufson EJ, Sanberg PR, et al. (1998) Fetal nigral grafts survive and mediate clinical benefit in a patient with Parkinson's disease. Mov Disord 13: 383-393. [Crossref]

32. Kordower JH, Freeman TB, Snow BJ, Vingerhoets FJ, Mufson EJ, et al. (1995) Neuropathological evidence of graft survival and striatal reinnervation after the transplantation of fetal mesencephalic tissue in a patient with Parkinson's disease. $N$ Engl J Med 332: 1118-1124. [Crossref]

33. Kordower JH, Rosenstein JM, Collier TJ, Burke MA, Chen EY et al. (1996) Functiona fetal nigral grafts in a patient with Parkinson's disease: chemoanatomic, ultrastructural, and metabolic studies. J Comp Neurol 370: 203-230. [Crossref]

34. Li JY, Englund E, Holton JL, Soulet D, Hagell P, et al. (2008) Lewy bodies in grafted neurons in subjects with Parkinson's disease suggest host-to-graft disease propagation. Nat Med 14: 501-503. [Crossref]

35. Li JY, Englund E, Widner H, Rehncrona S, Bjorklund A, et al. (2010) Characterization of Lewy body pathology in 12- and 16-year-old intrastriatal mesencephalic grafts surviving in a patient with Parkinson's disease. Mov Disord 25: 1091-1096. [Crossref]

36. Mendez I, Sanchez-Pernaute R, Cooper O, Vinuela A, Ferrari D, et al. (2005) Cell type analysis of functional fetal dopamine cell suspension transplants in the striatum and substantia nigra of patients with Parkinson's disease. Brain 128: 1498-1510. [Crossref]

37. Mendez I, Viñuela A, Astradsson A, Mukhida K, Hallett P, et al. (2008) Dopamine neurons implanted into people with Parkinson's disease survive without pathology for 14 years. Nat Med 14: 507-509. [Crossref]

38. Piccini P, Lindvall O, Björklund A, Brundin P, Hagell P, Ceravolo R, et al. (2000) Delayed recovery of movementrelated cortical function in Parkinson's disease after striatal dopaminergic grafts. Ann Neurol 48: 689-695. [Crossref]

39. Politis M, Wu K, Loane C, Quinn NP, Brooks DJ, et al. (2010) Serotonergic neurons mediate dyskinesia side effects in Parkinson's patients with neural transplants. Sci Transl Med 2: 38ra46. [Crossref]

40. Kefalopoulou Z, Politis M, Piccini P, Mencacci N, Bhatia K, et al. (2014) Longterm clinical outcome of fetal cell transplantation for Parkinson disease: two case reports. JAMA Neurol 71: 83-87. [Crossref]

41. Olanow CW, Goetz CG, Kordower JH, Stoessl AJ, Sossi V, et al. (2003) A doubleblind controlled trial of bilateral fetal nigral transplantation in Parkinson's disease. Ann Neurol 54: 403-414. [Crossref]

42. Ma Y, Tang C, Chaly T, Greene P, Breeze R, et al. (2010) Dopamine cell implantation in Parkinson's disease: long-term clinical and 18F-FDOPA PET outcomes. J Nucl Med 51: 7-15. [Crossref]

43. Roy NS, Cleren C, Singh SK, Yang L, Beal MF, et al. (2006) Functional engraftment of human ES cell-derived dopaminergic neurons enriched by coculture with telomeraseimmortalized midbrain astrocytes. Nat Med 12: 1259-1268. [Crossref]

44. Kriks S, Shim JW, Piao J, Ganat YM, Wakeman DR, et al. (2011) Dopamine neuron derived from human ES cells efficiently engraft in animal models of Parkinson's disease. Nature 480: 547-551. [Crossref]

45. Kirkeby A, Grealish S, Wolf DA, Nelander J, Wood J, et al. (2012) Generation of regionally specified neural progenitors and functional neurons from human embryonic stem cells under defined conditions. Cell Rep 1: 703-714. [Crossref]

46. Grealish S, Elsa D, Agnete K, Bengt M, Andreas H, et al. (2014) Human ESC-derived dopamine neurons show similar preclinical efficacy and potency to fetal neurons when grafted in a rat model of Parkinson's disease. Cell Stem Cell 15: 653-665. [Crossref]

47. Doi D, Bumpei S, Mitsuko K, Tetsuhiro K, Asuka M, et al. (2014) Isolation of human induced pluripotent stem cell-derived dopaminergic progenitors by cell sorting for successful transplantation. Stem Cell Rep 2: 337-350. [Crossref] 
48. Hargus G et al. (2010) Differentiated Parkinson patient-derived induced pluripotent stem cells grow in the adult rodent brain and reduce motor asymmetry in Parkinsonian rats. Proc Natl Acad Sci USA 107: 15921-15926. [Crossref]

49. Kikuchi T, Morizane A, Doi D, Onoe H, Hayashi T, et al. (2011) Survival of human induced pluripotent stem cell derived midbrain dopaminergic neurons in the brain of a primate model of Parkinson's disease. J Parkinson's Dis 1: 395-412. [Crossref]

50. Rhee YH, Ko JY, Chang MY, Yi SH, Kim D, et al. (2011) Protein-based human iPS cells efficiently generate functional dopamine neurons and can treat a rat model of Parkinson disease. J Clin Invest 121: 2326-2335. [Crossref]

51. Sundberg M, Bogetofte H, Lawson T, Smith G, Astradsson A, et al. (2013) Improved cell therapy protocols for Parkinson's disease based on differentiation efficiency and safety of hESC-, hiPSC-, and non-human primate iPSC-derived dopaminergic neurons. Stem Cells 31: 1548-1562. [Crossref]

52. Swistowski A, Peng J, Liu Q, Mali P, Rao MS, et al. (2010) Efficient generation of functional dopaminergic neurons from human induced pluripotent stem cells under defined conditions. Stem Cells 28: 1893-1904. [Crossref]

53. Turner M, Leslie S, Martin NG, Peschanski M, Rao M, et al. (2013) Toward the development of a global induced pluripotent stem cell library. Cell Stem Cell 13: 382 384. [Crossref]

54. Lindvall O (2015) Treatment of Parkinson's disease using cell transplantation. Philos Trans R Soc Lond B Biol Sci 370: 20140370. [Crossref]

Copyright: $\odot 2017$ Habibyar AF. This is an open-access article distributed under the terms of the Creative Commons Attribution License, which permits unrestricted use, distribution, and reproduction in any medium, provided the original author and source are credited. 